Haya: The Saudi Journal of Life Sciences

Abbreviated Key Title: Haya Saudi J Life Sci

ISSN 2415-623X (Print) |ISSN 2415-6221 (Online)

Scholars Middle East Publishers, Dubai, United Arab Emirates

Journal homepage: https://saudijournals.com

Review Article

\title{
Botanical Role, Sources, Bioactive Compounds in Medicinal and Genetically Modified Crops
}

Ebadet $\mathrm{Ali}^{{ }^{1 *}}$, Zarghoona $\mathrm{Naz}^{2}$, Bilqees Kanwal ${ }^{2}$, Syeda Ayesha Hamdani ${ }^{1}$, Rabia Rahmat ${ }^{3}$, Hira Tahir ${ }^{4}$, Summan $^{1}$, Salma Sharif ${ }^{1}$

${ }^{1}$ Department of Botany, Hazara University Mansehra, Pakistan

${ }^{2}$ Department of Botany, University of Agriculture Faisalabad, Pakistan

${ }^{3}$ Department of Botany, The Women University Multan, Pakistan

${ }^{4}$ Department of Botany, Government College Women University Faisalabad, Pakistan

DOI: $10.36348 /$ sjls.2022.v07i01.004

| Received: 07.12.2021 | Accepted: 13.01.2022 | Published: 24.01.2022

*Corresponding author: Ebadet Ali

Department of Botany, Hazara University Mansehra, Pakistan

\section{Abstract}

The chemical compounds extracted from medicinal plants have potential to evoke mental and social sensations in addition to maintain physical health. . Species of Asteraceae and Liliaceae play significant cardiovascular roles irrespective of exploring their toxicological aspects. Carbohydrates, proteins, lipids, nucleotides, fats, and steroids are the primary organic compounds which are involved in metabolism of essential developmental and growth functions of plants. The detrimental effects of environmental stress factors are suppressed by the gene expressions of ion transporters and water channel proteins present in the cell membranes incorporated with the up or downregulation of osmo-proctant osmolytes and essential proteins such as HSP and chaperones. Sunflower (Helianthus annuus L.) is an important crop known for its food, forage, and silage constituents. It is a prominent specie in Asteraceae family. Its seeds are enriched with edible oil-world's fourth largest oil source. The mineral elements, dietary fibers, and secondary metabolites such as carotenoids, flavonoids, tocopherols, saponins, tannins, alkaloids, chlorogenic acid, caffeic acid, peptides, phytosterols, triterpene glycosides, and vitamins contribute towards nutraceutical roles. Pot marigold (Calendula officinalis) possesses antibiotic, anti-inflammatory, and antifungal properties which allow its applications in preventing muscle spasms, treating sore throat and ulcers of duodenum and stomach, soothing eczema, healing wounds, and relieving rashes.

Keywords: Medicinally important phytochemicals, Applications, jatrorrhizine, oxyacanthine.

Copyright () 2022 The Author(s): This is an open-access article distributed under the terms of the Creative Commons Attribution 4.0 International License (CC BY-NC 4.0) which permits unrestricted use, distribution, and reproduction in any medium for non-commercial use provided the original author and source are credited.

\section{INTRODUCTION}

Life is sustained with a plenty of organic and inorganic materials, primarily derived from plants. Besides getting food and oxygen, an immense number of useful compounds are obtained from plants which comprise significant health benefits. On the other hand, natural source of cure (medicinal plants) retains effective and reliable qualities. The chemical compounds extracted from medicinal plants have potential to evoke mental and social sensations in addition to maintain physical health [1-3]
In the majority of the undeveloped world, particularly in rural, vernacular drugs, which include homoeopathy, is the only source of health care for people, whereas in the advanced world, complementary therapies, including the use of nutraceuticals, is vigorously marketed employing ethnomedicinal assumptions. Plant-based medicines like analgesics, morphine, and marijuana are used for both medicinal and recreational purposes. Various countries have used illegal drugs at different times, mainly due to the hazards associated with ingesting psychotic narcotics [4-6]. 


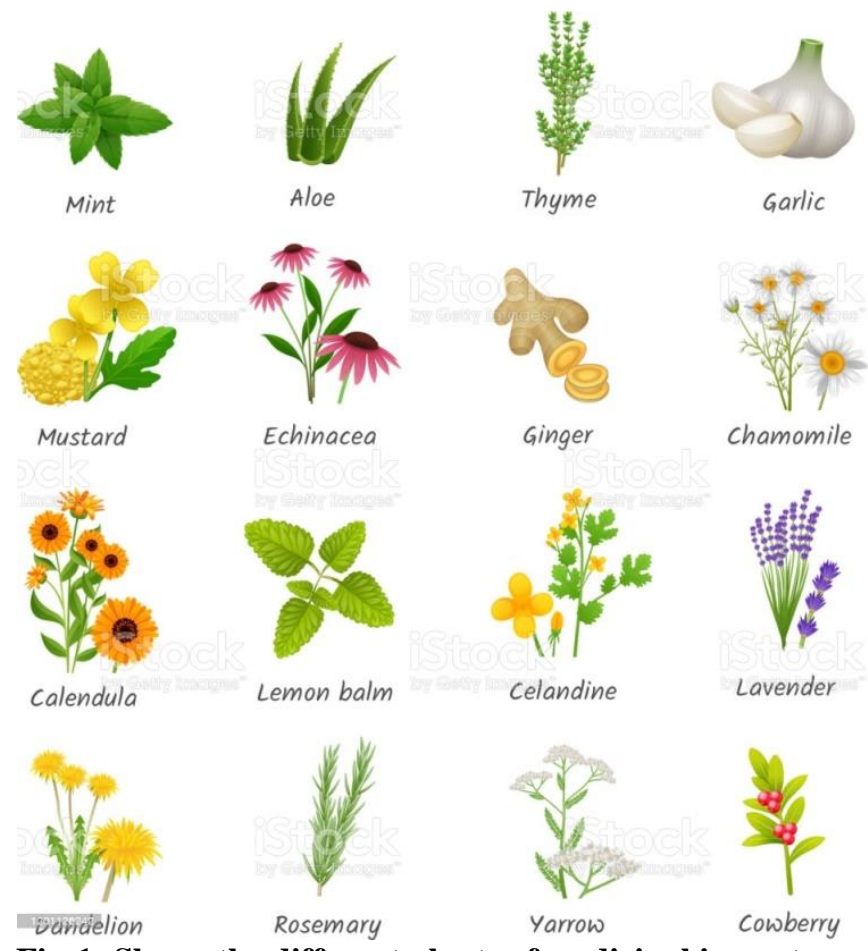

Fig-1: Shows the different plants of medicinal importance

\section{Botanical role, sources, bioactive compounds in medicinal}

Topical ointments were traditionally made by boiling natural herbs, wrapped them in a fabric, and putting the resultant parcels directly to the diseased injured or infected parts. Medicinal herbs are generally rough and fibrous; they must be prepared in some way before being used. Decoction, powdering, and alcohol extraction are all popular procedures for making herbal medications, and each yields a variety of chemicals. Decoction is the process of crushing and boiling plant material in water to create a liquid extraction that may be consumed or applied externally $[7,8]$. Powdering is the process of dehydrating and grinding plants material to produce a powder that may be crushed into pellets. When a substance in a medicinal plant has been recognized by medical advances, marketable supplies of the drugs can be produced or isolated from plant parts, creating a purified compound. When the substance in concern is complicated, extraction might be useful [9, $10]$.

Drugs manufactured of medicinal plants are usually considered safe assuming that consumption of all plants is harmless. However, it needs extra effort to explore and assess the toxicological levels present in some plants. Species of Asteraceae and Liliaceae play significant cardiovascular roles irrespective of exploring their toxicological aspects. Inclusion of a little fraction of toxic chemicals while extraction of chemical compounds from herbs may result in drastic side effects. This level of toxicity varies depending upon the method of extraction and the solvent used. Traditional methods of medicine preparation from medicinal plants are more susceptible to gain higher toxicological levels. Anyhow, this risk can be reduced to greater extent by conducting sustainable and precise practices $[11,12]$.

The use of plants extract in rescuing diseases has been intuitive in humans as illustrated by the ancient peoples in old ages. When people were unable to understand and communicate to each other, they had to struggle for the cure of their diseases. They totally depended upon the natural resources in their surroundings. With the passage of time and getting experience over the circumstances, they learnt a lot from each other and from their environment. Necessities raised their intellectual values [1, 7, 9]. Skills of agricultural farming and domestication of animals were the most successful adaptations and even in the recent times these are the prominent fields over worldwide. Besides this, treatment of various pathogenic diseases and accidental injuries was another challenging problem. No doctors and healthcare workers were there. Peoples used to utilize and manipulate their own homemade remedies which were originally produced of herbal sources. In this way usage of medicinal plants in curing illness and in mental addictions gradually unrestrained and got explicatory status [13-16].

Alo vera is an invasive, evergreen, perennial, succulent, cosmopolitan species. It belongs to family Asphodelaceae. It grows as a wild species especially in tropical, sub-tropical and arid climatic regions of the world. It has been used in topical ointments since over centuries. It has been utilised as a skin treatment in traditional medicine. Its usage may be traced back to the 4th millennium BCE. Aloin is the active compound 
Ebadet Ali et al., Haya Saudi J Life Sci, Jan, 2022; 7(1): 19-23

found in the semi-liquid latex of several Aloe species, was a major commercial component in market as laxative products when the producers could not provide necessary safety data material sheet of the product. Currently, after careful processing, Aloe vera is applied to the skin of the face as a moisturizer and anti-irritant to prevent nasal chafing. Cosmetics, napkins, lotions, detergents, sun protection, perfumes, shaving foam, and shampoos are all widely infused with Aloe sap or its derivatives [17-20].

Carbohydrates, proteins, lipids, nucleotides, fats, and steroids are the primary organic compounds which are involved in metabolism of essential developmental and growth functions of plants. In addition to these indispensable compounds, certain other important metabolic compounds, the secondary metabolites such as phenolics, terpenoids, alkaloids, amines, glycosides, glycosylates, etc. are also involved in necessary chemical reactions. They accomplish vital physiological functions in humans and animals. In this way, they utilized in great part of our nutritional and medicinal products [21-23].

The detrimental effects of environmental stress factors are suppressed by the gene expressions of ion transporters and water channel proteins present in the cell membranes incorporated with the up or downregulation of osmo-proctant osmolytes and essential proteins such as HSP and chaperones. Stresses such as heat, drought, or their combined effect is abolished by the accumulation of competent osmolytes. Most of these osmo-proctants are derived from the secondary metabolites of plants such as betaines, sugar alcohols, polyamines, and soluble carbohydrates [2426].

Antioxidants are the chemical compounds which prevent the oxidation reactions. There are numerous chemical reactions taking place within the cells of living organisms to drive life processes. It requires the availability of necessary chemicals and their correct orientation towards the proper mechanisms. A little deviation or deficiency of an essential element may lead to drastic consequences. Oxidation reactions result in the formation of free radicals as intermediates which turn on chain reactions damaging the cellular structures. Antioxidants inhibit the oxidation processes by removing these free radical intermediates and hence provide safe zone to the cells[27-29]. Diabetes is the detrimentally disorder triggered by various metabolic complications such as oxidative stress, hyperglycemia, dyslipidemia, advanced glycation, and inflammation. It stimulates deleterious effects in other tissues. In diabetics, in addition to infective interactions the chances of progression of other disorders through glucotoxicity and lipotoxicity may also arise $[1,11,19]$.
Family Asteraceae comprises the important genus of Cichorium which is majorly distributed in the regions of Asia and Europe with six species. Inulin, $\beta-2$ linked fructose polymer with linked residue of glucose, is the significant reserve carbohydrate in these species. Chicory (Cichorium intybus L.) is the representative member of this group. It is a fairly erect, woody perennial herb up to I meter in height carrying large basal leaves and an extensive tap root system $[30,31]$.

Sunflower (Helianthus annuus L.) is an important crop known for its food, forage, and silage constituents. It is a prominent specie in Asteraceae family. Its seeds are enriched with edible oil-world's fourth largest oil source subsequently to soybean, rapeseed, and peanut. The green sunflower plants are immense source of proteins and fats and hence used for forage and silage for livestock. It is basically native crop of North America and due its high nutritional values now being cultivated worldwide. Amazingly, the young shoots and florets of sunflower have been used traditionally in preparing tea and tinctures for their medicinal status (anti-inflammatory properties). Currently, it is grown widely as commercial crop for its nutritional and medicinal phytoconstituents. The mineral elements, dietary fibers, and secondary metabolites such as carotenoids, flavonoids, tocopherols, saponins, tannins, alkaloids, chlorogenic acid, caffeic acid, peptides, phytosterols, triterpene glycosides, and vitamins contribute towards nutraceutical roles. They perform various antiinflammatory, antioxidant, antimicrobial, cardiovascular, hypersensitive, and wound healing functions in human [32-34]. Transformation and regeneration in sunflower are defiant practices as these entail the competent cultures of cells and an effective approach of gene delivery. Vector mediated transformation method using Agrobacterium tumefaciens has been developed in embryonic split mature explants of the Ha-89 variety [21, 23, 37, 38].

Pot marigold (Calendula officinalis) is another important species of Asteraceae family. It is native to Southern Europe. It is one of the oldest cultivated flowering plants especially in England since 1200 AD. Oil extracted from its flowers possesses antibiotic, antiinflammatory, and antifungal properties which allow its applications in preventing muscle spasms, treating sore throat and ulcers of duodenum and stomach, soothing eczema, healing wounds, and relieving rashes [26, 29].

Sparrow grass (Asparagus officinalis) is a perennial herbaceous plant of Asparagaceae family. It grows up to $100-150 \mathrm{~cm}$ tall with branched stems, adventitious root system, and needle-like leaves. Its flowers are bell-shaped, greenish to yellow. Young shoots are edible but with very low nutritional values. It is a great source of minerals and vitamins such as magnesium, calcium, zinc, vitamin $\mathrm{B}_{6}$, niacin, rutin, folic acid, vitamin $\mathrm{K}, \mathrm{C}, \mathrm{E}$, and potassium, iron, 
Ebadet Ali et al., Haya Saudi J Life Sci, Jan, 2022; 7(1): 19-23

manganese, copper, phosphorus, selenium, and chromium. Its use as diuretic, contraceptive, and laxative flashbacks in prehistoric times. According to recent research investigations, it is proved useful remedy for rheumatism, neuritis, cancer, toothache relieve, lesions and face acne. It also stimulates hair growth $[11,18,19,35,36]$.

Thymus vulgaris has been used in foodstuffs for flavor, aroma, and preservation purposes. It also has been used in traditional medicines. Myrcene, $\alpha$ phellandrenes, $\beta$-phellandrenes, humulenes, thymol, and carvacrol are the important phytoconstituents present in the essential oil of Thymus vulgaris. These constituents retain significant antioxidant potential therefore this plant gains a pivotal status in medicinal field [20, 27, 29].

Berberis asiatica Roxb. is a well-known plant that produces numerous medicinally important phytochemicals including palmatine, berberine, jatrorrhizine, oxyacanthine, tetrahydropalmatine, and columbamine. It is 1.8 to 2.4 meters long shrub with acute, ovate, oblong, mucronate margin leaves; yellow umbellate flowers and oblong edible berries. It is naturally found at the altitudes of 600 to 2700 meters in Himachal Pradesh regions [33-38].

\section{CONCLUSION}

Different plants in the fields of plant sciences and agricultural sciences gain special attention because of their medicinal value. It is important to extract the natural compounds in those plants for treatment of various diseases. Any kind of diseases can be combated through advanced techniques. In recent era, synthetic drugs are widely adopted because of their fast rate of action but they also possess some side effects as well. To make the tinctures from organic matter, it is soaked in cold alcohol or distill spirits.

\section{REFERENCES}

1. Devi, G., Sudhakar, K., Vasupradaa, A. P., Sravya, V., Manasa, V., \& Yasaswini, E. (2021). Medicinal plants in india and it's antioxidant potential-A Review. Revista Geintec-Gestao Inovacao $E$ Tecnologias, 11(4), 1397-1405.

2. Chanda, S., Parekh, J., Vaghasiya, Y., Dave, R., Baravalia, Y., \& Nair, R. (2015). Medicinal plantsfrom traditional use to toxicity assessment: a review. International Journal of Pharmaceutical Sciences and Research, 6(7), 2652.

3. Castiglioni, A. (2019). A history of medicine. Routledge.

4. Rajasekaran, A., \& Pant, J. (2008). The genus Berberis linn.: A review. Pharmacognosy Review, 2(4).

5. Poitout, V., \& Robertson, R. P. (2008). Glucolipotoxicity: fuel excess and $\beta$-cell dysfunction. Endocrine reviews, 29(3), 351-366.
6. Bais, H. P., \& Ravishankar, G. A. (2001). Cichorium intybus L-cultivation, processing, utility, value addition and biotechnology, with an emphasis on current status and future prospects. Journal of the Science of Food and Agriculture, 81(5), 467-484.

7. El-Nekeety, A. A., Mohamed, S. R., Hathout, A. S., Hassan, N. S., Aly, S. E., \& Abdel-Wahhab, M. A. (2011). Antioxidant properties of Thymus vulgaris oil against aflatoxin-induce oxidative stress in male rats. Toxicon, 57(7-8), 984-991.

8. Zahin, M., Aqil, F., \& Ahmad, I. (2009). The in vitro antioxidant activity and total phenolic content of four Indian medicinal plants. International Journal of pharmacy and pharmaceutical Sciences, 1(1), 88-95.

9. Feldman, M., Smartt, J., \& Simmonds, N. W. (1995). Wheats, Evolution of crop plants, Harlow, UK Longman Scientific and Technical (pg. 185192).

10. Shewry, P. R., \& Hey, S. J. (2015). The contribution of wheat to human diet and health. Food and energy security, 4(3), 178-202.

11. Kattenberg, A. (1996). Climate models: projections of future climate. No. CONF-960146-. American Meteorological Society, Boston, MA (United States).

12. Royo, A., \& Abió, D. (2003). Salt tolerance in durum wheat cultivars. Spanish Journal of Agricultural Research, (3), 27-36.

13. Roche, P. E., Castaing, B., Chabaud, B., \& Hébral, B. (2001). Observation of the 12 power law in Rayleigh-Bénard convection. Physical Review E, 63(4), 045303.

14. Lin, W. C., \& Hsieh, C. C. (2005). Commercial application of Anoectochilus formosanus: immunomodulating activities. International Journal of Applied Science and Engineering, 3(3), 175-178.

15. Patel, S., Biswas, B., Rambabu, K., Sundaram, E. N., \& Arya, R. (2020). Pharmacognostical studies of Smilax aspera Linn.-A herbal drug. Indian Journal of Research in Homoeopathy, 14(4), 260.

16. Xu, S. Z., Xie, Y. H., Zhang, X. W., Liu, Y. Y., Wang, S. W., \& Lu, Y. (2013). Simultaneous determination of five anthraquinones in Shenkang injection by RP-HPLC. Chin Tradit Pat Med, 35, 90-93.

17. Sajjad, A., \& Subhani Sajjad, S. (2014). Aloe vera: An ancient herb for modern dentistry-A literature review. Journal of Dental Surgery, 2014.

18. Christaki, E. V., \& Florou-Paneri, P. C. (2010). Aloe vera: a plant for many uses. J Food Agric Environ, 8(2), 245-249.

19. Gao, Y., Kuok, K. I., Jin, Y., \& Wang, R. (2019). Biomedical applications of Aloe vera. Critical reviews in food science and nutrition, 59(sup1), S244-S256.

20. Dimou, C., Karantonis, H. C., Skalkos, D., \& Koutelidakis, A. E. (2019). Valorization of fruits 
by-products to unconventional sources of additives, oil, biomolecules and innovative functional foods. Current pharmaceutical biotechnology, 20(10), 776-786.

21. Yeboah, F. K., \& Konishi, Y. (2003). Mass spectrometry of biomolecules: Functional foods, nutraceuticals, and natural health products. Analytical letters, 36(15), 3271-3307.

22. Hoffmann, T., Kalinowski, G., \& Schwab, W. (2006). RNAi-induced silencing of gene expression in strawberry fruit (Fragariax ananassa) by agroinfiltration: a rapid assay for gene function analysis. The Plant Journal, 48(5), 818-826.

23. De Robertis, M., Sarra, A., D’oria, V., Mura, F., Bordi, F., Postorino, P., \& Fratantonio, D. (2020). Blueberry-derived exosome-like nanoparticles counter the response to TNF- $\alpha$-Induced change on gene expression in EA. hy926 cells. Biomolecules, 10(5), 742.

24. Namiki, M. (1990). Antioxidants/antimutagens in food. Critical Reviews in Food Science \& Nutrition, 29(4), 273-300.

25. Pokorný, J. (1991). Natural antioxidants for food use. Trends in Food Science \& Technology, 2, 223227.

26. André, C., Castanheira, I., Cruz, J. M., Paseiro, P., \& Sanches-Silva, A. (2010). Analytical strategies to evaluate antioxidants in food: a review. Trends in food science \& technology, 21(5), 229-246.

27. Bremer, K., \& Gustafsson, M. H. (1997). East Gondwana ancestry of the sunflower alliance of families. Proceedings of the National Academy of Sciences, 94(17), 9188-9190.

28. Barreda, V. D., Palazzesi, L., Tellería, M. C., Olivero, E. B., Raine, J. I., \& Forest, F. (2015). Early evolution of the angiosperm clade Asteraceae in the Cretaceous of Antarctica. Proceedings of the National Academy of Sciences, 112(35), 1098910994.
29. Gupta, R. K., \& Das, S. K. (1997). Physical properties of sunflower seeds. Journal of Agricultural Engineering Research, 66(1), 1-8.

30. Mirzabe, A. H., Khazaei, J., \& Chegini, G. R. (2012). Physical properties and modeling for sunflower seeds. Agricultural Engineering International: CIGR Journal, 14(3), 190-202.

31. Bailly, C., Leymarie, J., Lehner, A., Rousseau, S., Côme, D., \& Corbineau, F. (2004). Catalase activity and expression in developing sunflower seeds as related to drying. Journal of experimental botany, 55(396), 475-483.

32. Dulf, F. V., Pamfil, D., Baciu, A. D., \& Pintea, A. (2013). Fatty acid composition of lipids in pot marigold (Calendula officinalis L.) seed genotypes. Chemistry Central Journal, 7(1), 1-11.

33. Bissa, S., \& Bohra, A. (2011). Antibacterial potential of pot marigold. Journal of Microbiology and Antimicrobials, 3(3), 51-54.

34. Bielski, S., \& Szwejkowska, B. E. A. T. A. (2013). Effect of fertilization on the development and yields of pot marigold (Calendula officinalis L.). Herba Polonica, 59(2).

35. Petruş-Vancea, A. (2011). New techniques in Asparagus officinalis L. micropropagation. Proceedings, UASVM Bucharest, Series A, 54.

36. Stephens, J. M. (1994). Asparagus--Asgaragus Officinalis L. University of Florida Cooperative Extension Service, Institute of Food and Agriculture Sciences, EDIS.

37. Srivastava, S. K., Singh Rawat, A. K., \& Mehrotra, S. (2004). Pharmacognostic evaluation of the root of Berberis asiatica. Pharmaceutical biology, 42(6), 467-473.

38. Andola, H. C., Gaira, K. S., Rawal, R. S., Rawat, M. S. M., \& Bhatt, I. D. (2010). Habitat-Dependent Variations in Berberine Content of Berberis asiatica Roxb. ex. DC. in Kumaon, Western Himalaya. Chemistry \& biodiversity, 7(2), 415-420. 